\title{
ASSESSING THE INTERRELATIONS BETWEEN ORGANIZATIONAL LEARNING CULTURE AND ORGANIZATIONAL CITIZENSHIP BEHAVIOR IN THE PUBLIC SECTOR
}

\author{
Alona Eisenberg, Jelena Davidova, Svetlana Ignatjeva, \\ Alona Rauckienè-Michaelsson \\ Daugavpils University (Latvia), Klaipeda University (Lithuania)
}

\begin{abstract}
Survival of the organizations nowadays depends on their ability to learn how to properly and quickly increase their efficiency and performance and adapt to the changing environment. Creating an organizational learning culture (OLC) has achieved an increase in the survivability of organizations. This paper examines OCB and OLC questionnaires, tests their reliability and validity and adapts them to the public sector. This study analyses 161 questionnaires filled in by municipality employees of one of the northern cities in Israel.

KEY WORDS: organizational learning culture, organizational citizenship behavior, measurement development, multi-dimensional instrument.
\end{abstract}

\begin{abstract}
Anotacija
Šiuolaikinès organizacijos išlikimas priklauso nuo jos gebėjimo mokytis didinti veiklos efektyvumą ir sparčiai reaguoti ị pokyčius. Organizacijos mokymosi kultūros (OMK) sukūrimas didina jos išlikimo galimybes. Straipsnyje analizuojami organizacijos mokymosi kultūros ir organizacijos pilietiškumo (OP) klausimynai, tiriamas jų validumas bei patikimumas taikant juos viešajame sektoriuje. Iš viso analizuojamas 161 klausimynas, užpildytas vieno šiaurès Izraelio miesto savivaldybės darbuotojų. Atliekant tyrimą siekiama analizuoti sąsajų tarp OMK ir OP raišką viešajame sektoriuje. PAGRINDINIAI ŽODŽIAI: organizacijos mokymosi kultūra, organizacijos pilietiškumas, matavimų tobulinimas, multidimensis instrumentas.
\end{abstract}

DOI: http://dx.doi.org/10.15181/tbb.v79i2.1779

\section{Introduction}

In a dynamic and changing world, organizations need to compete for scarce resources. Organizations should become more intelligent, profitable and capable to survive. Hence the organization's need is to find internal resources without increasing expenditures. In recent decades, the research field has focused on finding the human resources and the factors that influence the employees' willingness to invest in their work beyond the formal definition of the job without expecting any reward. One of the organization's goals is to find appropriate methods to motivate employees to contribute from their free will, since it is a key factor in its success. 
The activity of organizations in a rapid, chaotic, turbulent and uncertain environment, and the need to adjust to changes, has made organizational learning a major issue .Fast and adequate adaptation to the fast evolving environment means that organizations need to be able to make internal changes at a rate at least similar to those changes that occur in the external environment and even faster. In order to make this possible, there is a need for employees called 'caring', 'investors' and 'proactive'. These workers come to work even when they are not healthy; they help co-workers without expecting any compensation and think from the point of view of organizational needs.

Organizations have to increase their collective learning capacity if they want to continue and exist in parallel to rapid social and technological changes and hastening competition. They need to increase their ability to change by accelerating the development of new products, processes and services (Mirkamali, Thani, Alami, 2011). The organization should become to be a 'learning organization' which according to Watkins \& Marsick (1993) is an organization that learns continuously and transforms itself. Such organizations carry out learning processes and create Organizational Learning Culture (OLC) - processes of knowledge acquisition, dissemination and exploitation that are important for an organization's competitiveness and survival.

Moreover, expectations from employees today are undergoing changes. In order to learn a new technology and to adopt it, the employees require new skills, and need to be more creative and competent. To achieve this, there is a need for employees who volunteer to fulfil their tasks beyond their defined role, beyond the job's definition and the level he/she are committed to. Organ (1988) called this behavior 'Organizational Citizenship Behavior' (OCB) and emphasized that it as an important factor in assisting the organization to reach its goals.

Although all other systems in our life have changed, the public sector, which is in the center of this research, remains conservative and inflexible. Routine work, the poor physical environment of the workplace, lack of competition, low wages, lack of a system of rewards and appropriate reinforcement: all result in lack of personal willingness to invest beyond the minimum requirements and definition of the job.

The aim of this research is to analyze the interrelationships between OCB and OLC in the public sector. This paper examines OCB and OLC questionnaires, adapts them to the public sector and tests their reliability and validity.

\section{Literature Review}

\subsection{Organizational learning culture}

Organizations learn through the experiences and activities of individual members of the organization. Organizational learning will not occur without dedicating 
time and creating structures and mechanisms that allow the existence of learning processes that are assimilated in the organization's routine (Engleharrdt, Simmons, 2002). These structures include a) frequent meetings for solving problems; $b$ ) flexible time for meetings; c) regular activities for professional development; d) shared preparation period; e) cross-department team meetings etc.

Jung \& Takeuchi (2010) claimed that the organizational culture provides rules, norms and values for organizational members sharing information, reaching agreements and acting on its results. A learning culture is an integral part of organizational behavior that occurs as a continuous process of improvement. An organizational learning culture is focused on basic assumptions, beliefs, values and behaviors that are associated with learning organizations (Schein, 2010). The characteristics of organizational learning culture are a) fast response; b) flexibility; c) integration; d) entrepreneurship; e) innovation.

Watkin and Marsick (2003) developed the dimensional questionnaire (DLOQ) that is designed to measure learning culture in organizations. This questionnaire has seven dimensions of the learning organization culture:

- Continuous learning - learning is designed into work so that people can learn on the job.

- Inquiry and dialogue - the culture is changed to support questioning, feedback and experimentation.

- Collaboration and team learning - groups are expected to learn together and work together; collaboration is valued by the culture and rewarded.

- Creating systems to capture and share learning - both high- and low-technology systems to share learning are created and integrated with work; access is provided; systems are maintained.

- Empowering people toward a collective vision - responsibility is distributed closely to decision making so that people are motivated to learn what they are held accountable for.

- Connecting the organization to its environment - people are helped to see the effect of their work on the entire enterprise; people scan the environment and use information to adjust work practices.

- Strategic leadership - leader's model, champion, and support learning.

The theory of Watkin and Marsick (2003) explains how people shape culture for learning. They propose a learning process at two levels: learning at the individual level and at the organizational level. They support the idea that organizational culture is built by leaders and other key people, who learn from their experience, influence the learning of others, and create an environment of expectations.

Organizational learning culture has found wide expression in the studies in recent decades, examining its effect on job's satisfaction, turnover intention, orga- 
nizational commitment, organizational performance, organizational learning process, organization leader's impact (Egan, Yang, Bartlett, 2004; Joo, Lim, 2009; Hung, Yang, Lien, McLean, Kuo, 2010; Joo, Park, 2010; Song, Jeung, Cho, 2011; Emami, Moradi, Idrus, Almutairi, 2012).

The theoretical framework of Watkins and Marsick (2003) is the basis of the study at hand.

\subsection{Organizational citizenship behaviors (OCB)}

The first 'Organizational citizenship behavior' (OCB) was defined by Smith, Organ \& Near in 1983. They describe the behaviors that go beyond the role prescriptions to contribute to organizational functioning. According to Organ $(1988$, p. 4), OCB reflects "individual behavior that is discretionary, not directly or explicitly recognized by the formal reward system and that is the aggregate which promotes the effective functioning of the organization". OCB is not written in any job's definition and results occur from people's own personal extra effort (Kaya, 2015).

Bateman \& Organ (1983)classified OCB as helping voluntarily other employees, providing innovative suggestions to improve the organization, not taking advantage of employees rights, not requesting unnecessary leaves, participating in the elective meetings and avoiding complaints. Jackson (2009) described OCB as beneficial behavior of workers, which was not prescribed but occurred freely to help others achieve the task at hand.

According to Organ's (1988) theory, organizational citizenship behavior has five dimensions (Table 1).

Table 1. Value of an Organizational Citizenship Behavior

\begin{tabular}{|l|l|}
\hline \multicolumn{1}{|c|}{ Dimension } & \multicolumn{1}{c|}{ Definition } \\
\hline Altruism & $\begin{array}{l}\text { Comprises all voluntary behavior, specifically aimed at helping } \\
\text { others in an organizationally relevant issue or in relation to problems } \\
\text { in the organization (Kamer, 2001) }\end{array}$ \\
\hline Conscientiousness & $\begin{array}{l}\text { Is the behavior that reflects the genuine acceptance and adherence of } \\
\text { workplace rules, regulations, and procedures in a manner above what } \\
\text { is expected (Podsakoff et al., 2000) }\end{array}$ \\
\hline Sportsmanship & $\begin{array}{l}\text { Is defined as "a willingness to tolerate the inevitable inconveniences } \\
\text { and impositions of work without complaining" (Organ, 1990, p. 96) }\end{array}$ \\
\hline Courtesy & $\begin{array}{l}\text { Comprises behavior that includes informing other employees before } \\
\text { the decisions that may affect them (Deluga, 1995) }\end{array}$ \\
\hline Civic Virtue & $\begin{array}{l}\text { Is characterized by behaviors that indicate an employee's deep } \\
\text { concerns and active interest in the life of the organization (Law, } \\
\text { Wong \& Chen, 2005) }\end{array}$ \\
\hline
\end{tabular}


According to Oplatka (2004; 2009), the employee's work life includes many activities and tasks that are beyond the formal definition of the employee's role, given to their consideration and desire, and very much contribute to the organization's functioning and its success. OCB develops the effective performance of the organization, elevates the organization as a whole and recommends it to other parties (Williams, Anderson, 1991).

Since the establishment of the OCB concepts, numerous studies had been conducted, which examined the connection between organizational citizenship behavior and other organizational phenomena, such as job satisfaction (Williams, Anderson, 1991; Talachi, Gorji, Boerhannoeddin, 2014), personal commitment (Tepper et al, 2004), turnover intention (Egan, Yang, Bartlett, 2004), interdependence and team's identification (Van Der Vegt et al, 2005), professional (Cohen, Kol, 2004), organizational politics (Vigoda, 2000), organizational climate (Farooqui, 2012) and organizational support (Islam, Khan, Ahmad, Ahmed, 2014).

This research will use the five-category model developed by Organ (1988).

\section{Theoretical Framework}

Kaya (2015) suggested that OCB is closely related to organizations' learning identities and commitment among its members. When employees feel that their organization allow them to learn, to experience, to make mistakes and to learn from the mistakes without being accused, they will be willing to invest in their work and show the kind of behavior suggested by OCB. The employee should have the knowledge, ability and opportunity to behave according to the predictions of organizational citizenship behavior (Ahmadi et al., 2014). Islam, Khan, Aamir \& Ahmad (2013) assume that learning values widen the perceptions of employees and they start thinking in a new manner, instead of performing formal tasks i.e. helping their colleagues to achieve the desired outcomes of the organization for its success. This means that learning values increase the citizenship among employees. Based on detailed literature review and determining the basic dimensions of both independent and dependent variables, Figure 1 shows the research conceptual model.

Therefore, the basic hypothesis is to measure the relationship between OLC and $\mathrm{OCB}$ in the public sector and deduct the following: organizational learning culture (OLC) is positively related to organizational citizenship behavior (OCB) in the public sector. 


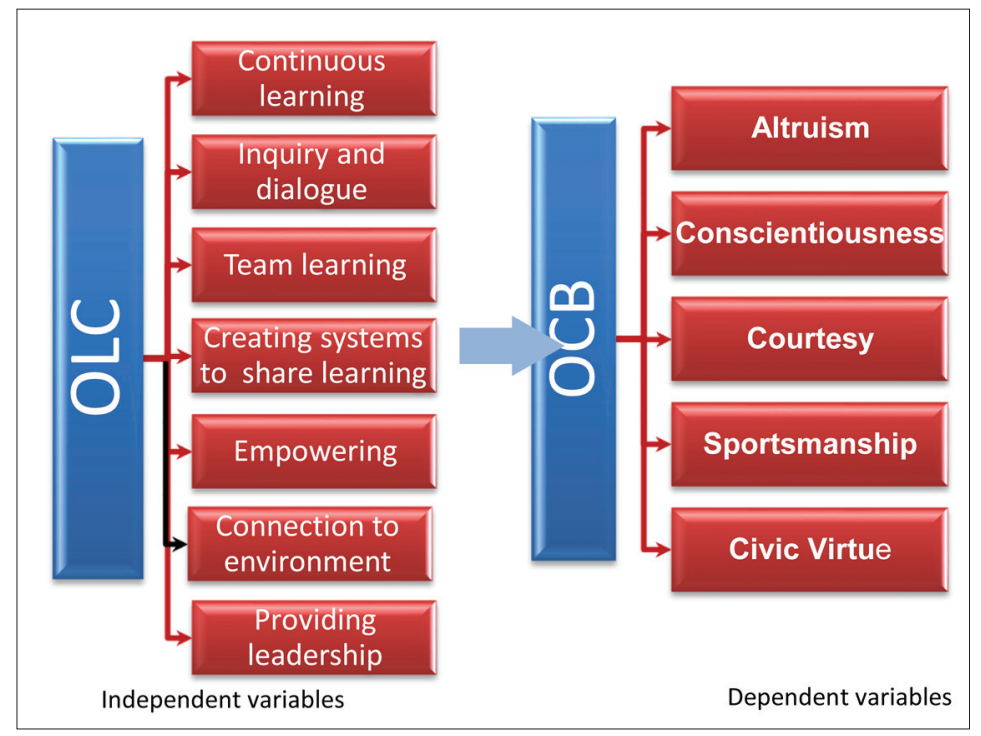

Figure 1. Conceptual Model of the Interrelation between OLC and OCB

\section{Research Methodology}

\subsection{Samples}

The population of this research is the municipality employees from all of departments: Education, Welfare, the Treasury, Sanitation, Immigration and Integration, Maintenance and Engineering; all of those are from a municipality located in the north of Israel. The choice of this specific municipality was made due to the researchers' access to this population. This municipality employs about 500 employees. The sample had 161 respondents, 52 men (32.3\%) and 109 women (67.7\%) from various departments. The questionnaire was also distributed to professional workers (some in managerial positions) and also to non-professionals. Half of respondents are over the age of 46, quarter of them are over 57 . The respondents' age varied between 19 and 67. The average age of the respondents was 46.5 years. 132 respondents $(82 \%)$ work full time, 29 of them (18\%) work part time. Work experience range was from several months to 42 years while the average was 12.6 years. More than half of respondents (52.3\%) were employed more than 10 years. Almost half of the respondents $(49.2 \%)$ had only a matriculation certificate. 


\subsection{Measures}

The study population was examined using two structured questionnaires: the Organizational Learning Culture Questionnaire and the Organizational Citizenship Behavior Questionnaire. Each employee was asked to fill out an anonymous questionnaire, which consisted of organizational learning and self-evaluation features of OCB. The employees received a comprehensive explanation of the research, the nature and complexity of the questionnaires, with an emphasis on the fact that the data will not be disclosed to any person. The average time to fill each questionnaire was 15-20 minutes. The response rate was $100 \%$, since the questionnaire was distributed by the researcher himself / herself, together with the approval of the organization's management. It was made clear to the employees that they would not be identified according to the questionnaires and the information would be received and processed only statistically.

The questionnaire consisted of three separate parts:

- Section Aincludes biographical data such as gender, age, level of education, actual position time (full or partial) and work time.

- Section Bisassessed by 46 itemsincluding the measuring dimensions of Organization Learning Culture (OLC) adopted from instrument developed by Watkins and Marsick (2003) and had been adjusted to Public sector. OLC was measured based on seven indicators. Continuous learning was measured using 8 items, dialogue and inquiry was measured using 3 items, team learning and collaboration was measured using 5 items, embedded system was measured using 6 items, empowerment was measured using 5 items, systems connections was measured using 5 items and strategic leadership was measured using 6 items.

- Section C: Organizational Civic Behavior (OCB) of employees is examined by 23 items which were based upon five main indicators according to Organ (1998) research. Civil virtue was measured using 5 items, conscientious was measured using 3 items, altruism was measured using 3 items, courtesy was measured using 5 items and sportsmanship was measured using 3 items.

The items in the surveys are with a 5-point Likert-type response scale ranging from 1 (strongly disagree) to 5 (strongly agree). An option to answer 'non-relevant' was also provided.

\section{Data Analysis and Result}

Reliability is a characteristic that reflects the consistency of the measured results. According Goswami, reliability is the consistency throughout a series of me- 
asurements (Goswami, 2011). The Cronbach's Alpha was used to evaluate coherence of the indicators identified. Cronbach's Alpha for Continuous learning was 0.893 , dialogue and inquiry was 0.742 , team learning was 0.78 , embedded system was 0.806 , empowerment was 0.818 , systems connections was 0.816 , strategic leadership was 0.876 , Civil virtue was 0.643 , conscientious was 0.679 , altruism was 0.926 , courtesy was 0.67 and sportsmanship was 0.834 . For all formed scales, the Cronbach's Alpha coefficient is not lower than 0.670, which allows considering them as internally consistent and reliable. This, in turn, makes it possible to calculate the aggregated scores on scales as the arithmetic mean of their indicators.

The descriptive statistics of the factors is shown in Table 3 and Figure 2. The factor Continuous learning has the highest average. All components of OLC are highly estimated by respondents (Figure 2). The average score is not below 3.35. Respondents ranked Continuous learning, Strategic leadership, and Systems connections as the highest components. The average estimates for these components are in the range from 3.7 to 3.72, and according to the Paired Samples Test for dependent samples, no significant differences between these estimates were observed. The lowest component is Empowerment $($ Mean $=3.35)$. Half of the respondents do not exceed 3.4, and 25\% do not exceed 2.8 .

Table 2. Descriptive the Statistics of the OLC Factors

\begin{tabular}{|l|l|l|l|l|}
\hline \multirow{2}{*}{} & Mean & Median & \multirow{2}{*}{ Mode } & Std. Deviation \\
\cline { 3 - 5 } & & & & \\
\hline Continuous learning & 3.72 & 3.88 & 4.00 & .81 \\
\hline Dialogue and inquiry & 3.62 & 3.67 & 4.33 & .85 \\
\hline Team learning and collaboration & 3.42 & 3.60 & $3.60 \mathrm{a}$ & .83 \\
\hline Embedded systems & 3.62 & 3.67 & $3.67 \mathrm{a}$ & .76 \\
\hline Empowerment & 3.35 & 3.40 & 3.00 & .84 \\
\hline Systems connections & 3.70 & 3.80 & 4.00 & .81 \\
\hline Strategic leadership & 3.71 & 3.83 & 4.00 & .86 \\
\hline
\end{tabular}

The evaluation of all OCB components is statistically significant (see Table 3). The factor Altruism (Mean = 4.61) is the most highly valued. Half of the respondents gave it the score of 5. The factor Sportsmanship rated as the lowest (Mean = 3.25). Half of the respondents did not have this score above 3. This component has the largest range of ratings $($ Std. Deviation $=1.29)$ (see Figure 4). 


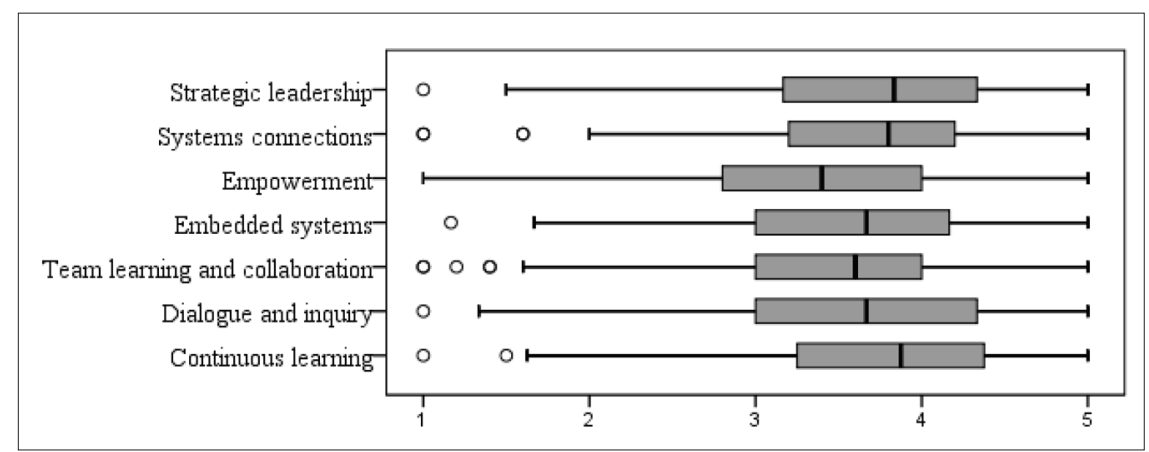

Figure 2. Boxplot of the OLC Factors

Table 3. Descriptive the Statistics of the OCB Factors

\begin{tabular}{|c|c|c|c|c|}
\hline & Mean & Median & Mode & Std. Deviation \\
\hline Civil virtue & 3.76 & 3.75 & 4.00 & .76 \\
\hline Conscientious & 4.44 & 4.50 & 5.00 & .59 \\
\hline Altruism & 4.61 & 5.00 & 5.00 & .66 \\
\hline Courtesy & 4.10 & 4.33 & 4.67 & .84 \\
\hline Sportsmanship & 3.25 & 3.00 & 5.00 & 1.29 \\
\hline
\end{tabular}

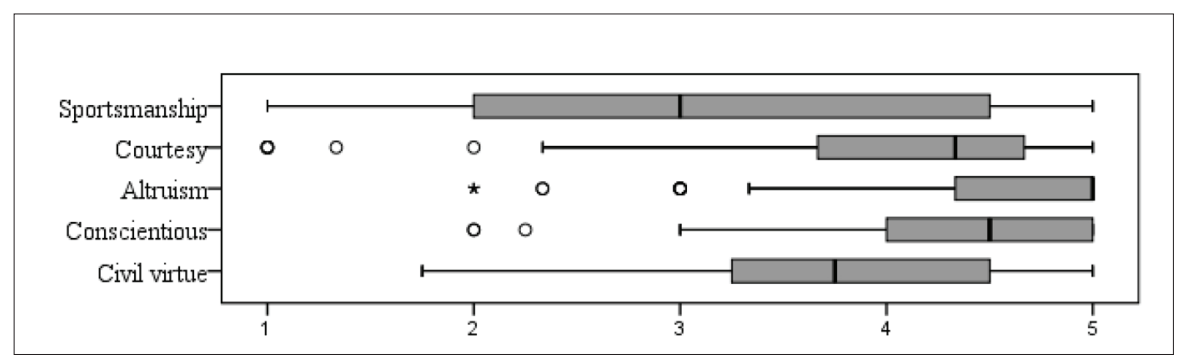

Figure 3. Boxplot of the OCB Factors 
Between some of the OLC and OCB factors was observed direct significant correlation. Such OCB components as Civil Virtue and Conscientious correlate with all components of OLC (see Table 4).

Table 4. Correlation between OLC and OCB Factors

\begin{tabular}{|l|l|l|l|l|}
\hline & Civil Virtue & Conscientious & Altruism & Courtesy \\
\hline Continuous learning & $.348^{* *}$ & $.329 * *$ & $.162^{*}$ & .063 \\
\hline Dialogue and inquiry & $.193^{*}$ & $.282^{* *}$ & .007 & .063 \\
\hline $\begin{array}{l}\text { Team learning and } \\
\text { collaboration }\end{array}$ & $.233^{* *}$ & $.301^{* *}$ & .086 & $.164 *$ \\
\hline Embedded systems & $.314^{* *}$ & $.372^{* *}$ & .087 & .088 \\
\hline Empowerment & $.361^{* *}$ & $.389^{* *}$ & .136 & .068 \\
\hline Systems connections & $.362^{* *}$ & $.412^{* *}$ & .107 & $.164 *$ \\
\hline Strategic leadership & $.356^{* *}$ & $.378^{* *}$ & .135 & .065 \\
\hline
\end{tabular}

The strongest direct relationship exists between Systems connections and Conscientious $(r=0.412)$ (see Figure 4). Between such OCB factors as Altruism and Courtesy and OLC factors was observed a very weak correlation.

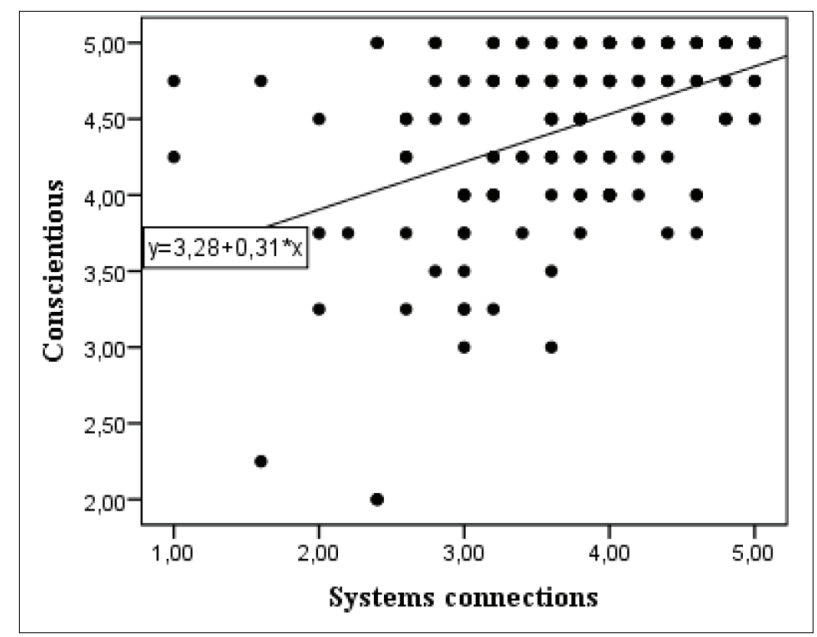

Figure 4. Diagram of Direct Linear Regression Scattering in the Plane of Conscientious and Systems Connections

The relationship between Sportsmanship and some factors of OLC is non-linear (see Table 5). When Sportsmanship is lower than $<3$, one can observe an inverse 
relationship, when Sportsmanship is higher or equal $>=3$, the nature of the connection is changed to direct (Figure 5).

Table 5. Correlation Coefficients between Sportsmanship and OLC Factors on Different Ranges of Change Sportsmanship

\begin{tabular}{|l|l|l|}
\hline \multicolumn{1}{|c|}{ OLC Factors } & \multicolumn{2}{c|}{ Level of Sportsmanship } \\
\hline & $1-3$ & $3-5$ \\
\hline Continuous learning & -.171 & .233 \\
\hline Dialogue and inquiry & -.172 & .072 \\
\hline Team learning and collaboration & $-.257^{*}$ & .113 \\
\hline Embedded systems & $-.262^{*}$ & $.234^{*}$ \\
\hline Empowerment & $-.214^{*}$ & $.209^{*}$ \\
\hline Systems connections & -.182 & .266 \\
\hline Strategic leadership & -.136 & .267 \\
\hline
\end{tabular}

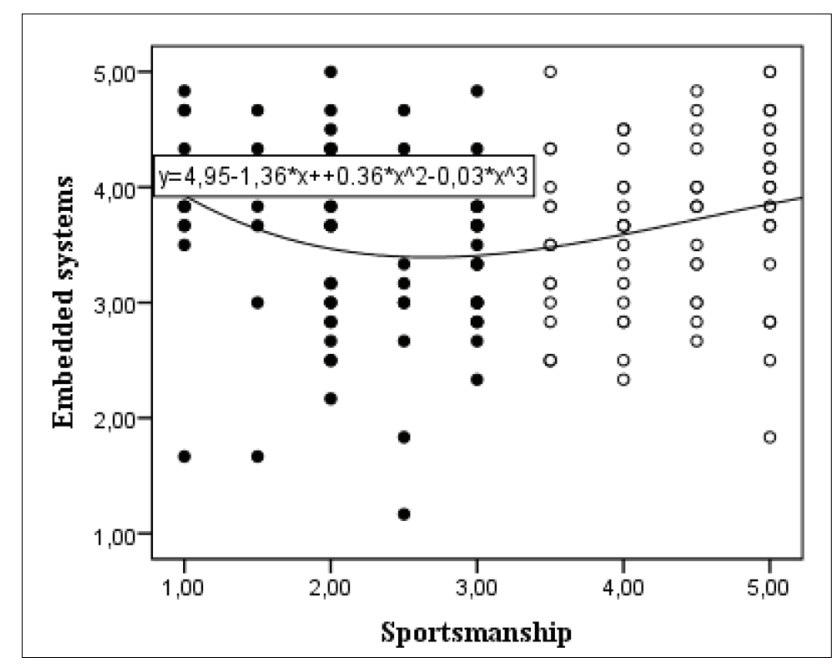

Figure 5. Diagram of Dispersion in the Plane of Sportsmanship and Embedded Systems

\section{Discussion and Conclusion}

This survey study aimed to investigate the issue of assessing the interrelations between OLC and OCB. To achieve this purpose, seven basic dimensions of OLC consisted of continuous learning, dialogue and inquiry, team learning and collaboration, embedded system, empowerment, systems connections and strategic le- 
adership; five basic dimensions of OCB consisted of altruism, conscientiousness, sportsmanship, courtesy and civic virtue, have been identified.

The study found that there is significant correlation between such factors of OCB as Civil virtue and Conscientious with all factors of OLC. It means that there is a positive relationship between two variables. In fact, an increase in OLC of the organization leads to an increase in the OCB of their employees, particularly in Civil Virtue and Conscientious factors.

Thus, OLC could be considered as a significant moderator and predictor of organizational citizenship behavior. However, a nonlinear correlation was observed between Sportsmanship and some factors of OLC.

Based on that result, it can be concluded that OLC has a positive significant effect on Organizational Civic Behavior. OLC has an important role in the process of strengthening of OCB. It means that in organizations that encourage learning, involve employees in organizational processes, share in decision making, OCB of employees is higher.

It is recommended to managers of organizations to encourage OLC through the reinforcement of employees' education, creating a supportive learning atmosphere, promoting their knowledge and participation in training courses, improving networking, in order to provide more organizational citizenship behavior.

\section{Limitation and Future Research}

This study was limited to investigate the moderation role of OLC to OCB in one public organization - municipality. Future research should increase the population examined to more municipalities and compare the results. It would be also recommended to investigate and research whether those results would be the same in other public organizations.

The current research has several limitations which provide opportunities for further research. First, the sample size for this study was relatively small $(n=161)$. According to this, the generalizability of the findings is limited: only one municipality employees participated in the survey to test research hypotheses. In future research it is necessary to examine the data by using a larger sample size from different municipalities. Second, this study only examined the direct impact of OLC on OCB.

Future research should deal with the cluster analysis in space of the main factors which possible to have groups of employees with similar profiles that characterize their attitude to the organization - employer. 


\section{References}

Ahmadi, A., Daryani, S. M., Bevrani, H. (2014). Evaluation of organizational learning process based on Marquardt Model. Case study: Municipality of Noor City, Iran. International Journal of Management and Innovation 6(1): 52-61.

Bateman, T. S., Organ, D. W. (1983). Job satisfaction and the good soldier: The relationship between affect and employee citizenship. Academy of Management Journal 26: 587-595.

Cohen, A., Kol, Y. (2004). Professionalism and organizational citizenship behavior: An empirical examination among Israeli nurses. Journal of Managerial Psychology 19(4): 386-405.

Deluga, R. J. (1995). The relation between trust in the supervisor and subordinate organizational citizenship behavior. Military Psychology 7(1): 1-16.

Egan, T. M., Yang, B., Bartlett, K. R. (2004). The effects of organizational learning culture and job satisfaction on motivation to transfer learning and turnover intention. Human Resource Development Quarterly 15(3): 279-301.

Emami, R., Moradi, E., Idrus, D., Almutairi, D. O. (2012). Investigating the relationship between organizational learning culture, job satisfaction and turnover intention in it SMEs. International Journal of Innovative Ideas 12(1): 8-23.

Engleharrdt, C. S., Simmons, P. R. (2002). Creating an organizational space for learning. The Learning Organization 9(1): 39-47.

Farooqui, M. R. (2012). Measuring organizational citizenship behavior (OCB) as a consequence of organizational climate (OC). Asian Journal of Business Management 4(3): 294-302.

Goswami, M. (2011). Measurement and Evaluation in Psychology and Education. Hyderabad: Neel Kamal publications Ltd.

Hung, R. Y. Y., Yang, B., Lien, B. Y. H., McLean, G. N., Kuo, Y. M. (2010). Dynamic capability: Impact of process alignment and organizational learning culture on performance. Journal of World Business 45: 285-294.

Islam, T., Khan, S. R., Ahmad, U. N., Ahmed, I. (2014). Exploring the relationship between POS, OLC, job satisfaction and OCB. Procedia - Social and Behavioral Sciences 114: 164-169.

Islam, T., Khan, S. R., Aamir, M., Ahmad, U. N. U. (2013). Organizational learning culture, social exchange relations and multifoci citizenship behaviors: A Literature Survey Approach. World Journal of Management and Behavioral Studies 1(1): 6-13.

Jackson, J. C. (2009). Organizational Citizenship Behaviors, Collective Teacher Efficiency and Student Achievement in Elementary Schools: Doctoral Dissertation. Retrieved from ProQuest Dissertation and Theses database.

Joo, B. K., Lim, T. (2009). The effects of organizational learning culture, perceived job complexity, and proactive personality on organizational commitment and intrinsic motivation. Journal of Leadership \& Organizational Studies 16(1): 48-60.

Joo, B. K., Park, S. (2010). Career satisfaction, organizational commitment, and turnover intention: The effects of goal orientation, organizational learning culture and developmental feedback. Leadership \& Organization Development Journal 31: 482-500.

Jung, Y., Takeuchi, N. (2010a). Performance implications for the relationships among top management leadership, organizational culture, and appraisal practice: Testing two theory-based models of organizational learning theory in Japan. The International Journal of Human Resource Management 21(11): 1931-1950.

Kamer, M. (2001). Organizational Trust, Organizational Commitment and their Effects on Organizational Citizenship Behaviors: Master's thesis. Marmara University, Istanbul, Turkey. Retrieved from https://tez.yok.gov.tr/ UlusalTezMerkezi/

Kaya, A. (2015). The relationship between spiritual leadership and organizational citizenship behaviors: A research on school principals' behaviors. Educational Sciences: Theory \& Practice 15(3): 597-606. 
Alona Eisenberg, Jelena Davidova, Svetlana Ignatjeva, Alona Rauckienè-Michaelsson

Law, S. K., Wong, C., Chen, X. Z. (2005). The construct of organizational citizenship behavior: Should we analyze after we have conceptualized? In D. L. Turnipseed (ed.). Handbook of Organizational Citizenship Behavior. New York: Nova Science Publishers, p. 47-65.

Mirkamali, S. M., Thami, F. N., Alami, F. (2011). Examining the role of transformational leadership and job satisfaction in the organizational learning of an automotive manufacturing company. Procedia - Social and Behavioral Sciences 29: 139-148.

Oplatka, I. (2009). Organizational citizenship behavior in teaching: The consequences for teachers, pupils and the school. International Journal of Educational Management 23: 375-389. Retrieved from http://dx.doi.org/10.1108/09513540910970476

Oplatka, I. (2004). The Components of 'Organizational Citizenship Behavior' among School Teachers. The German-Israel Foundation, Jerusalem.

Organ, D. W. (1990). The motivational basis of organizational citizenship behavior. In B. M. Staw, L. L. Cummings (eds.). Research in Organizational Behavior 12: 43-72. Greenwich, CT: JAI Press.

Organ, D. W. (1988). Organizational Citizenship Behavior: The good soldier syndrome. Lexington: Lexington Books.

Podsakoff, P. M., Mackenzie, S. B., Paine, J. B., Bachrach, D. G. (2000). Organizational citizenship behaviors: A critical review of the theoretical and empirical literature and suggestions for future research. Journal of Management 26(3): 513-563.

Schein, E. H. (2010). Organizational Culture and Leadership. Jossey-Bass: Wiley Imprint.

Smith, C. A., Organ, D. W., Near, J. P. (1983). Organizational citizenship behavior: Its nature and antecedents. Journal of Applied Psychology 68(4): 653-663.

Song, J. H., Jeung, C. W., Cho, S. H. (2011). The impact of the learning organization environment on the organizational learning process in the Korean business context. Learning Organization 18: 468485.

Talachi, R. K., Gorji, M. B., Boerhannoeddin, A. B. (2014). The role of jobs satisfaction in employees' OCB. Collegium Antropologicum 38(2): 429-436.

Tepper, B. J., Duffy, M. K., Hoobler, J., Ensley, M. D. (2004). Moderators of the relationships between coworkers' organizational citizenship behavior and fellow employees' attitudes. Journal of Applied Psychology 89(3): 455-465.

Van der Vegt, G., Bunderson, S. (2005). Learning and performance in multidisciplinaryteams: The importance of collective team identification. Academy of Management Journal 48(3): 532-547.

Vigoda, E. (2000). The relationship between organizational politics, job attitudes, and work outcomes: Exploration and implications for the public sector. Journal of Vocational Behavior 57: 326-347.

Watkins, K. E., Marsick, V. J. (1993). Sculpting the Learning Organization: Lessons in the art and science of systemic change. Jossey-Bass Inc.

Watkins, K. E., Marsick, V. J. (2003). Demonstrating the value of an Organization's learning culture: The dimension of the learning organizational questionnaire. Advances in Developing Human Resources 5(2): 132-151.

Williams, L. J., Anderson, S. E. (1991). Job satisfaction and organizational commitment as predictors of organizational citizenship and in-role behaviors. Journal of Management 17: 601-617. 